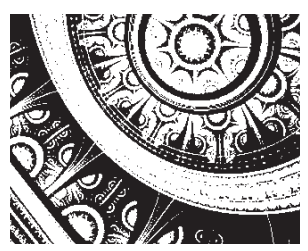

https://doi.org/10.5559/di.28.1.04

\title{
QUALITY OF WORKING LIFE AMONG 50+ EMPLOYEES ACROSS THE EU: A DOUBLE JEOPARDY FOR CROATIAN OLDER WORKERS
}

Zvonimir GALIĆ, Maja PARMAČ KOVAČIĆ

Faculty of Humanities and Social Sciences, Zagreb

Maja VEHOVEC

The Institute of Economics, Zagreb

UDK: 005.32-053.88(497.5:4-6EU):331.101.32

Izvorni znanstveni rad

Primljeno: 17. 11. 2017.

One of the most pressing concerns in the EU nowadays seems to be the impact of ageing population on the economy. In Croatia the problem is even more pronounced considering that a significant proportion of workforce leaves the labor market before the legal retirement age. One of potential reasons for early retirement might be the quality of working life (QWL) among older employees. Aim of our study was to explore QWL among older Croatian workers by comparing them to younger Croatian workers and their EU peers. Using the data from the 6th European Working Conditions Survey conducted during 2015 on over 30000 participants, we compared the QWL of Croatian workers older than 50 with younger workers and their peers from well-established market economies of Western Europe and transitional Central and Eastern European countries.

Research showed that older workers in Croatia perceive their QWL lower than younger Croatian workers and their peers from other EU countries (especially economic security and autonomy in work). We believe that these findings are, at least partially, the reason for their early retirement.

Keywords: older workers, quality of working life, job quality, job satisfaction, Croatia, EU

$\triangle \quad$ Zvonimir Galić, Department of psychology, Faculty of Humanities and Social Sciences, University of Zagreb, Ivana Lučića 3, 10000 Zagreb, Croatia. 
Our study is motivated by current demographic trends in Croatia and the EU and their future social and economic consequences. The two main demographic trends are a general decline in fertility and an increase in life expectancy (Eurostat, 2015a, 2015b). These trends influence the population structure (e.g., ratio of $65+$ citizens to working age population) and have important long-term consequences for societies because of the burden they put on healthcare and pension funds. For example, due to demographic trends, the projected ratio of dependent $65+$ individuals to working age population ( $15-64$ years) is expected to increase sharply during the next decades (European Commission, 2018). This trend is especially pronounced in the EU new member states of Central and Eastern Europe, including Croatia, because general demographic trends will not be mitigated with immigration. In fact, the unfavorable demographic trends are additionally worsened by the fact that the countries are losing large numbers of their workers who are emigrating to better-developed EU economies (Župarić-Iljić, 2016), and a significant portion of workers leaving the workforce to retire before the full retirement age (e.g., Baloković, 2010; Hoff, 2011; Vehovec, 2008).

All these indicators point to the need for people to continue working to maintain the retirement systems and make health funds sustainable. In 2010 the European Commission established a target of $50 \%$ employment rate among the 55 to 64 years age group. According to the "2018 Ageing Report: Economic and Budgetary Projections for the EU Member States (2016-2070)" that was published in May 2018, the participation rate (i.e., percentage of population employed or looking for a job within the labor force) among older Croatian workers is relatively low and will remain so in the foreseeable future if significant changes are not introduced. In Table 1, we list participation rates in Croatia and the EU observed in 2016 and projected for the period 2020-2030. As might be seen from Table 1 , the participation rates are consistently lower in Croatia in comparison to the EU average. However, the most striking differences can be observed among the older groups of workers (55-64) where the expected difference between Croatia and the EU, if nothing changes, will amount to over $20 \%$ in 2030.

The aim of the research described in our study was to explore the quality of working life among Croatian employees older than 50 in order to gain an understanding about the reasons that drive their decision to voluntarily leave the workforce. We believe that the contribution of our study is two-fold. First and foremost, findings from such a study will point to 
(1) TABLE 1

Comparison of participation rates between Croatia and EU average in the period 2016-2030 the aspects of working life that should be changed in order to reverse the unfavorable trends in the participation rates among older workers related to voluntary withdrawal from the workforce. Second, such a study should contribute to our general understanding of how the quality of working life depends on workers' age, socio-economic circumstances, and their interaction, and, thus, contributes to the growing body of research on the ageing workforce (e.g., Truxillo, Cadiz, \& Hammer, 2015).

\begin{tabular}{|c|c|c|c|c|c|c|c|c|}
\hline \multirow[b]{2}{*}{ Age group } & \multicolumn{2}{|r|}{2016} & \multicolumn{2}{|r|}{2020} & \multicolumn{2}{|r|}{2025} & \multicolumn{2}{|r|}{2030} \\
\hline & Croatia & EU28 & Croatia & EU28 & Croatia & EU28 & Croatia & EU28 \\
\hline Total (15-64) & 65.7 & 72.9 & 67.2 & 73.7 & 67.9 & 74.1 & 68.8 & 74.5 \\
\hline Young (15-24) & 37.3 & 42.0 & 41.3 & 42.3 & 38.8 & 41.3 & 40.0 & 42.4 \\
\hline Prime-age (25-54) & 82.0 & 85.5 & 82.9 & 85.9 & 83.5 & 86.2 & 84.0 & 86.2 \\
\hline Older (55-64) & 42.3 & 59.1 & 43.5 & 62.4 & 45.4 & 66.0 & 47.3 & 68.0 \\
\hline
\end{tabular}

Note: The source is The 2018 Ageing Report: Economic and Budgetary Projections for the EU Member States (2016-2070).

\section{Quality of working life: Definition and measurement}

Quality of working life (QWL), as a term, was introduced in the late 1960s. One of the first definitions of QWL was offered by Davis (1983), who defined it as "the quality of the relationship between employees and the total working environment, with human dimensions added to the usual technical and economic considerations" (p. 80). However, although several more definitions of the QWL have been offered since (e.g., Korunka, Hoonakker, \& Carayon, 2008; Attewell \& Rule, 1984; Kraut, Dumais, \& Koch, 1989), none were universally accepted. So, it seems justifiable only to use QWL as an "umbrella term" (Šverko \& Galić, 2014, p. 558) that includes different aspects of the work environment which are considered beneficial for the individual such as physical working conditions, type of employment contracts, size of wages, quality of relations among employees, autonomy and participation in making decisions.

Following the work of Efraty and Sirgy (1990) and Šverko and Galić (2014), in this paper we adopted a psychological perspective of the QWL, by seeing it as a subjective construct that reflects individuals' work-related experiences related to their psychological needs. According to this perspective, people aspire to satisfy their psychological needs and the extent to which the environment responds favorably to their needs determines their affective experiences - they experience more positive affective experiences when the congruence between the individual and environment is greater (Efraty \& Sirgy, 1990; Naylor, Pritchard, \& Ilgen, 1980; Raynor, 1982). This means 
DRUŠ. ISTRAŽ. ZAGREB GOD. 28 (2019), BR. 1, STR. 69-87

GALIĆ, Z., PARMAČ KOVACIĆ, M., VEHOVEC, M.: QUALITY OF WORKING. that workers bring a cluster of their psychological needs to the organization and the extent to which these needs are satisfied through their work experiences determines the level of experienced QWL (Efraty \& Sirgy, 1990).

Šverko and Galić (2014) identified four major dimensions of QWL from the psychological perspective. These four dimensions correspond to the principal categories of human needs that are, with some variations, included in most major motivational theories such as Maslow's (1954) Hierarchy of Needs Theory, Alderfer's (1972) ERG Theory, McClelland's (1985) Acquired Needs Theory, Deci and Ryan's $(1985,2000)$ Self-Determination Theory or Hackman and Oldham's (1976) Job Characteristics Theory. According to this QWL model, the first dimension is economic security. It refers to having a stable income, which is essential for the satisfaction of "basic" human needs that stem from human physiology and the needs for physical security. The dimension also includes needs related to psychological security at work, as reflected in the probability that an individual will keep a job or, if needed, find a new one. The second dimension, social relations at work, refers to the amount and the quality of interpersonal relations at work that are important for an individual's well-being. These needs comprise the desire to interact, to be connected to a group, and the experience of caring for others and to be cared for by others. The third dimension, labelled meaningful work, refers to the amount in which workers perceive they are making a worthwhile contribution to their and the organization's work outcomes. According to Šverko and Galić (2014), meaningful job follows from work activities that allow creativity and provide the feelings of usefulness and achievement. And finally, the fourth dimension, autonomy in work and participation in making decisions, concerns autonomy as the universal urge of humans to be "causal agents in their lives" (Šverko \& Galić, 2014 , p. 560). Playing an active role in making decisions was shown to enhance both intrinsic motivation and well-being (Deci \& Ryan, 2000).

Research has demonstrated that QWL is related to different work behaviors and work outcomes. For example, Havlovic (1991) found that higher QWL is related to a decrease in the frequency of absenteeism, minor accidents, grievances and quits, whereas Efraty and Sirgy (1990) reported that QWL is positively related to organizational identification, job satisfaction, job involvement, job effort, job performance, and negatively to personal alienation. Furthermore, Louis (1998) showed that QWL is strongly positively related to work commitment and sense of efficacy at the workplace. A significant impact of the QWL perception on organizational commitment has been 
DRUŠ. ISTRAŽ. ZAGREB GOD. 28 (2019), BR. 1 STR. 69-87

GALIĆ, Z., PARMAČ KOVACIĆ, $M$. VEHOVEC, M.: QUALITY OF WORKING. also recently shown in a study by Huang, Lawler, and Lei (2007). Finally, studies by Lee, Singhapakdi, and Sirgy (2007) and Koonmee, Singhapakdi, Virakul, and Lee (2010) revealed that, in addition to organizational commitment, QWL generally has a positive relationship with job satisfaction and team spirit. A clear pattern emerged from this research. On the one hand, satisfactory QWL leads to different "positive" work outcomes like increased job satisfaction, enhanced job performance and organizational commitment. On the other hand, low QWL leads to "negative" work behaviors and outcomes such as increased frequency of absenteeism, accidents or voluntary turnover.

\section{OUR STUDY}

Studies on the QWL among Croatian workers are generally scant, and those that dealt with the subject mostly relied on samples of convenience (e.g. Šverko \& Galić, 2009) or concluded about the levels of QWL in Croatia without comparing it to relevant benchmarks (e.g., Galić \& Plećaš, 2012) such as QWL among the other EU countries. Recent inclusion of Croatia in the European Working Conditions Survey (EWCS, Eurofund, 2012, 2017), where representative samples of Croatian workers participated along with the samples from other European countries, provided the data that could be used to draw stronger conclusions about QWL in Croatia. In a recent paper, Šverko and Galić (2014), using the data from the 5th ECWS that was conducted in 2010, explored QWL among Croatian workers and compared it to the other EU countries. Building on the model of psychological needs employees satisfy at their workplaces that was described earlier, they identified a set of questions in the EWCS survey that should capture the four QWL dimensions. After subjecting the items to a thorough psychometric analysis, the authors compared Croatian participants to the other EU countries. As the standard of comparison, they used two groups of countries: EU17, which consisted of 15 well-established market economies from Western Europe (Austria, Belgium, Denmark, Finland, France, Greece, Germany, Ireland, Italy, Luxemburg, the Netherlands, Portugal, Spain, Sweden, and the UK) together with two Mediterranean island countries (Malta and Cyprus), and EU10, which comprised of 10 Central and Eastern European (CEE) transitional countries (Bulgaria, the Czech Republic, Estonia, Hungary, Latvia, Lithuania, Poland, Romania, Slovakia, and Slovenia). The results of their analysis showed that Croatia, as other CEE countries, lagged behind the Western European countries in QWL, particularly in the economic security dimension. 
DRUŠ. ISTRAŽ. ZAGREB GOD. 28 (2019), BR. 1, STR. 69-87

GALIĆ, Z., PARMAČ

KOVACIC, M.,

VEHOVEC, M.:

QUALITY OF WORKING.
However, none of the studies focused on the QWL among older Croatian workers. Considering that data from the 6th (2015) EWCS became available recently, we aimed to explore QWL in that demographic group by comparing it to (a) younger Croatian workers but also (b) to their EU peers. We examined their QWL using four major dimensions of QWL proposed by Šverko and Galić (2014), and using the same comparison groups (i.e., EU17 and EU10). In addition to these four dimensions of QWL, we explored general job satisfaction, as a direct consequence of QWL, which affects the individual's work motivation and job performance (Judge \& Klinger, 2007). In addition to the main aim of our study (i.e., QWL among 50+ workers), we also wanted to check how the trends about the QWL of Croatian workers reported by Šverko and Galić (2014) held over a five-year period.

\section{Materials and methods}

\section{Participants}

A multi-stage, stratified, random sample of respondents participated in the study. In total, 35.765 participants from $27 \mathrm{EU}$ Member States $(\mathrm{N}=23.768$ from EU17 and $\mathrm{N}=10.985$ from EU10 countries) and Croatia $(\mathrm{N}=1.012)$ participated in the study. All residents of the countries aged 15 or older (16 or older in Bulgaria, Spain and the UK) and in employment at the time of the survey were eligible as participants. People were considered to be in employment if they had worked for pay or profit for at least an hour in the week preceding the participation in the study. Each country was divided into sections based on region and degree of urbanization. In each section, a number of primary sampling units was drawn randomly, in each unit, a random sample of households was drawn and, finally, in each household an employed person with the upcoming birthday was chosen as the participant. Male and female participants were equally represented in the sample. In this sample $35.8 \%$ of the participants were over 50 years of age.

\section{Instruments}

Quality of Working Life measure. In this study, we built on the Quality of Working life measure, developed by Šverko and Galić (2014). It measures four QWL components: economic security (3 items), social relations at work ( 3 items), meaningfulness at work ( 2 items) and autonomy in work and participation in decision-making (5 items). The QWL scales with all corresponding items and response scales are listed in Table 2. The measure was similar but not identical to the QWL measure from Šverko and Galić (2014) since a few items in the 6th 
Economic security

1. Considering all my efforts and achievements in my job, I feel I get paid appropriately.

2. I might lose my job in the next 6 months.

3. My job offers good prospects for career advancement.

Social relationship at work

1. I generally get on well with my work colleagues.

2. Your manager helps and supports you.

3. Your colleagues help and support you.

Meaningfulness at work

1. Your job gives you the feeling of work well done.

2. You have the feeling of doing useful work.

Autonomy and participation in making decisions

1. You can take a break when you wish.

2. You are involved in improving the work organization or work process of your department or organization.

3. You have a say in the choice of your working colleagues

4. You can influence decisions that are important for your work.

5. You are consulted before objectives are set for your work.

(1) TABLE 2

The Quality of

Working Life measure:

Dimensions and items
Note: For the Economic security and Social relations at work dimensions, the participants' task was to evaluate themselves on a five-point importance response scale ranging from 1 (strongly disagree) to 5 (strongly agree), whereas for the Meaningfulness at work and Autonomy in work/ Participation in decision-making, their task is to self-report on a five-point likelihood response scale ranging from 1 (never) to 5 (always).

Before conducting our main analyses, we wanted to check construct validity of our QWL measure on the 6th EWCS dataset. In that respect, we conducted two sets of analyses. First, we conducted confirmatory factor analyses on the total sample and separately on the subsamples of younger (15-49 years) and older $(50+)$ participants. The four-factor model with independent error terms showed acceptable fit to the data (whole sample: GFI $=0.97$; RMSEA $=0.060$; RMSEA 90\% CI [0.058, 0.061 , younger than 49: GFI $=0.97$; RMSEA $=0.054$; RMSEA $90 \%$ CI $[0.053,0.056]$; older than 50: GFI $=0.96$; $\mathrm{RMSEA}=0.062$; RMSEA 90\% CI $[0.066,0.070])$. Second, we correlated the scores on the QWL dimensions with a well-being index that was also part of the EWCS survey. If our reasoning about importance of QWL holds and satisfaction of the psychological needs at work is essential for individuals' life experience, all QWL dimensions should correlate positively with a well-being index. Our analyses showed that in total sample as well as in both age groups, all the QWL dimensions correlated positively with general well-being. The full list of correlations is given in Table A in the Appendix.

Cronbach's alphas of the four scales in this study were very similar to those reported by Šverko and Galić (2014): 0.46 for economic security ( 0.49 under 50 years; 0.45 over 50 years), 0.67 for social relations at work ( 0.67 under 50 years; 0.66 over 
DRUŠ. ISTRAŽ. ZAGREB GOD. 28 (2019), BR. 1, STR. 69-87

GALIĆ, Z., PARMAČ KOVACIĆ, M., VEHOVEC, M.: QUALITY OF WORKING...

\section{Procedure}

\section{RESULTS}

50 years), 0.73 for meaningfulness at work ( 0.74 under 50 years; 0.73 over 50 years), 0.78 for autonomy in work and participation in decision-making (0.78 in both age groups).

Job satisfaction measure. Participants' job satisfaction was measured with only one item "In general, are you very satisfied, satisfied, not very satisfied or not at all satisfied with the working conditions at your main paid job?" and participants gave their responses on a four-point scale $(1-$ not at all satisfied; 4 - very satisfied).

Earlier research demonstrated acceptable reliability levels for single item measures of general job satisfaction (cf. Judge \& Klinger, 2007), probably due to the fact that this is a highly salient attitude in an individual's life and, thus, easy to capture even with a one-item scale.

The study used the dataset collected within the 6th European Working Conditions Survey (EWCS).

The data was collected from February until September 2015 , through an interview that was conducted in the participants' homes. The interviews were based on a carefully prepared and pre-tested questionnaire in the national language of the participants' country. Interviews were carried out by experienced interviewers with at least one-year experience in survey research.

Descriptive statistics for our study variables are given in Table 3 . The participants achieved theoretically average values on economic security and autonomy in work and participation in decision-making and slightly above theoretically average scalar values on social relations, meaningfulness at work and job satisfaction. The correlations among the four components of QWL are positive and moderate in size $(0.27$ to 0.41$)$. Moreover, all of them moderately correlated with job satisfaction (0.32 to 0.48 ), which we take as additional evidence for the construct validity of our QWL measure.

With the aim of testing the difference in QWL and job satisfaction between younger and older workers in the three groups of countries (EU17, EU10 and Croatia), we performed a series of 2 (age group) x 3 (county) ANOVAs. ${ }^{1}$ We used the age of 50 for delineating older workers because it is the age after which the chance of age-related disability significantly increases and it is often used as a cut-off age in research about older workers (Truxillo et al., 2015), and policy-related documents (e.g., European Commission, 2016). Descriptive statistics for the age and country subgroups and ANOVA results are presented in Table 4. 


\begin{tabular}{|c|c|c|c|c|c|c|c|c|c|c|}
\hline Variable & $M(S D)$ & 1 & 2 & 3 & 4 & 5 & 6 & 7 & 8 & 9 \\
\hline 1 Gender $^{1}$ & $1.05(0.50)$ & & & & & & & & & \\
\hline 2 Age & $43.85(12.56)$ & -0.01 & & & & & & & & \\
\hline 3 Country $1^{2}$ & $0.02(0.17)$ & $0.00 \quad 0$ & 0.00 & & & & & & & \\
\hline 4 Country $2^{3}$ & $0.66(0.47)$ & $-0.05^{* *}-0$ & $-0.02^{* *}-($ & $-0.24^{* *}$ & & & & & & \\
\hline 5 Country $3^{4}$ & $0.31(0.46)$ & $0.05^{* *} 0$ & $0.02^{* *}-($ & $-0.14^{* *}$ & $-0.94^{* *}$ & & & & & \\
\hline 6 QWL: economic security & $3.34(0.91)$ & $-0.06^{* *}-0$ & $-0.07^{* *}-$ & $-0.04^{* *}$ & $0.06^{* *}$ & $-0.05^{* *}$ & & & & \\
\hline 7 QWL: social relations & $4.08(0.77)$ & $0.01^{*}-0$ & $-0.06^{* *}-$ & $-0.02^{* *}$ & $0.04^{*}$ & $-0.03^{*} \quad 0$ & $0.34^{*}$ & & & \\
\hline 8 QWL: meaningfulness & $4.29(0.79)$ & $0.02 * * 0$ & $0.10^{* *}-$ & -0.01 & $0.04^{* *}$ & $-0.04 * * 0$ & $0.27^{*}$ & $* 0.41^{* *}$ & & \\
\hline 9 QWL: autonomy & $3.03(1.05)$ & $-0.09^{* *} 0$ & $0.08^{* *}-(-2-2-2$ & $-0.02^{* *}$ & 0.01 & $0.00 \quad 0$ & $0.40^{*}$ & $* 0.38^{* *}$ & $0.34^{* *}$ & \\
\hline 10 Job satisfaction & $3.08(0.69)$ & $0.01 \quad-0$ & $-0.01-(-1)$ & $-0.03^{* *}$ & $0.07^{* *}$ & $-0.06^{* *} 0$ & $0.48^{*}$ & $* 0.36^{* *}$ & $0.32^{* *}$ & $0.32^{* *}$ \\
\hline \multirow{3}{*}{$\begin{array}{l}\text { D TABLE } 3 \\
\text { Descriptive statistics } \\
\text { and intercorrelations } \\
\text { of variables }\end{array}$} & \multicolumn{10}{|c|}{$\begin{array}{l}\text { Note. }{ }^{1} \text { male }=1 \text {, female }=2 ; 21=\text { Croatia; } 0=\text { EU17 and EU10; } 31=\text { EU17; } 0= \\
\text { Croatia and EU10; }{ }^{4} 1=\text { EU17; } 0=\text { Croatia and EU10. }\end{array}$} \\
\hline & & & & \multicolumn{7}{|c|}{ ANOVA F-ratio } \\
\hline & & & & \multicolumn{2}{|c|}{$M(S D)$} & Age & \multicolumn{2}{|c|}{ Country } & \multicolumn{2}{|c|}{ Age Country } \\
\hline \multirow[t]{25}{*}{$\begin{array}{l}\text { TABLE } 4 \\
\text { Comparison between } \\
\text { group of workers } \\
\text { under the age of } 50 \\
\text { and group of workers } \\
\text { of } 50 \text { and over on four } \\
\text { quality of working life } \\
\text { dimensions and job } \\
\text { satisfaction (Study 2) }\end{array}$} & $\begin{array}{l}\text { Economic } \\
\text { security }\end{array}$ & $\begin{array}{l}\text { EU17 } \\
\text { EU10 } \\
\text { Croatia }\end{array}$ & $\begin{array}{l}<50 \\
50+ \\
<50 \\
50+ \\
<50 \\
50+\end{array}$ & \multicolumn{2}{|c|}{$\begin{array}{l}3.41(0.92) \\
3.33(0.88) \\
3.36(0.90) \\
3.12(0.91) \\
3.23(0.95) \\
2.97(0.94)\end{array}$} & $68.72^{* *}$ & \multicolumn{2}{|c|}{ ** $\quad 79.27^{* *}$} & \multicolumn{2}{|c|}{$23.83^{* *}$} \\
\hline & Social & EU17 & $<50$ & \multirow{6}{*}{\multicolumn{2}{|c|}{$\begin{array}{l}4.12(0.75) \\
4.06(0.77) \\
4.07(0.76) \\
4.01(0.82) \\
4.03(0.79) \\
3.91(0.86)\end{array}$}} & \multirow[t]{6}{*}{$13.05^{* *}$} & \multirow{6}{*}{\multicolumn{2}{|c|}{$18.04^{* *}$}} & \multirow{6}{*}{\multicolumn{2}{|c|}{0.52}} \\
\hline & relations & & $50+$ & & & & & & & \\
\hline & & EU10 & $<50$ & & & & & & & \\
\hline & & & $50+$ & & & & & & & \\
\hline & & Croatia & $a<50$ & & & & & & & \\
\hline & & & $50+$ & & & & & & & \\
\hline & Meaning- & EU17 & $<50$ & \multirow{6}{*}{\multicolumn{2}{|c|}{$\begin{array}{l}4.26(0.78) \\
4.39(0.72) \\
4.21(0.83) \\
4.30(0.83) \\
4.22(0.80) \\
4.33(0.79)\end{array}$}} & \multirow{6}{*}{\multicolumn{2}{|c|}{$33.65^{* *}$}} & \multirow[t]{6}{*}{$32.97^{* *}$} & \multirow{6}{*}{\multicolumn{2}{|c|}{2.49}} \\
\hline & fulness at & & $50+$ & & & & & & & \\
\hline & work & EU10 & $<50$ & & & & & & & \\
\hline & & & $50+$ & & & & & & & \\
\hline & & Croatia & $a<50$ & & & & & & & \\
\hline & & & $50+$ & & & & & & & \\
\hline & Autono- & EU17 & $<50$ & \multirow{6}{*}{\multicolumn{2}{|c|}{$\begin{array}{l}2.99(1.04) \\
3.14(1.06) \\
3.05(1.03) \\
2.99(1.06) \\
2.94(1.08) \\
2.83(1.13)\end{array}$}} & \multirow[t]{6}{*}{0.15} & \multirow{6}{*}{\multicolumn{2}{|c|}{$14.65^{* *}$}} & \multirow{6}{*}{\multicolumn{2}{|c|}{$30.31^{* *}$}} \\
\hline & my/par- & & $50+$ & & & & & & & \\
\hline & ticipation & EU10 & $<50$ & & & & & & & \\
\hline & & & $50+$ & & & & & & & \\
\hline & & Croatia & $a<50$ & & & & & & & \\
\hline & & & $50+$ & & & & & & & \\
\hline & Job satis- & EU17 & $<50$ & \multirow{6}{*}{\multicolumn{2}{|c|}{$\begin{array}{l}3.11(0.71) \\
3.13(0.69) \\
3.05(0.64) \\
2.99(0.64) \\
3.02(0.74) \\
2.89(0.75)\end{array}$}} & $11.53^{* *}$ & & $93.83^{* *}$ & 17.18 & $8^{* *}$ \\
\hline & faction & & $50+$ & & & & & & & \\
\hline & & EU10 & $<50$ & & & & & & & \\
\hline & & & $50+$ & & & & & & & \\
\hline & & Croatia & $a<50$ & & & & & & & \\
\hline & & & $50+$ & & & & & & & \\
\hline
\end{tabular}

${ }^{*} p<0.05 ;{ }^{* *} p<0.01 . ;<50$ - workers under the age of $50 ; 50+-$ workers aged 50 and over; EU17 = developed economies from Western Europe; EU10 = transitional Central and Eastern European countries; $M=$ mean; $S D=$ standard deviation. 
DRUŠ. ISTRAŽ. ZAGREB GOD. 28 (2019), BR. 1, STR. 69-87

GALIĆ $Z_{\text {., }}$ PARMAČ

KOVACIC, M.,

VEHOVEC, M.:

QUALITY OF WORKING.
Important for our research goal, the performed ANOVAs resulted with statistically significant main age effects on three QWL dimensions (economic security, social relations and meaningfulness at work) and job satisfaction. Older workers perceive their economic security (Myounger $=3.39$ vs. Molder $=3.26$ ), social relations at work $($ Myounger $=4.10 \mathrm{vs}$. Molder $=4.04)$ and job satisfaction (Molder $=3.08$ vs. Myounger $=3.09$ ) significantly lower than younger workers. The only QWL dimensions that older workers see more favorable than younger workers is meaningfulness of their work (Myounger $=4.25 \mathrm{vs}$. Molder $=4.36$ ).

Considering the main effect of the country, significant differences were obtained for all four QWL dimensions and job satisfaction. Post-hoc testing (Tukey's HSD test) revealed significant differences between Croatian workers and EU17 and/or EU10 workers on three out of four QWL dimensions and job satisfaction. Croatian workers rate their social relations at work and job satisfaction significantly lower than the workers from EU17 countries, whereas they estimate their economic security and autonomy at work lower than the workers from both EU17 and EU10 countries.

Significant interactions on two QWL dimensions (economic security and autonomy/participation in making decisions) and job satisfaction reveal that differences between older and younger workers are not equally profound in the three groups of countries (Figure 1).

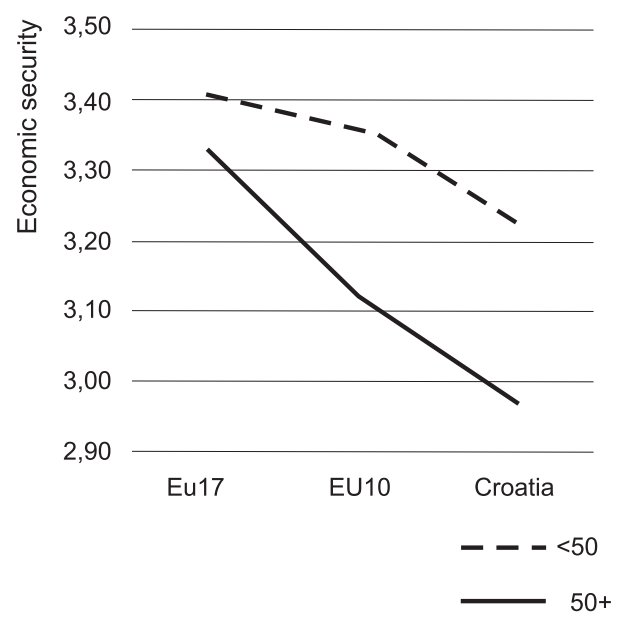

(1) FIGURE 1

Interaction effects between age and country groups for the economic security, autonomy/participation and job satisfaction dimensions of QWL
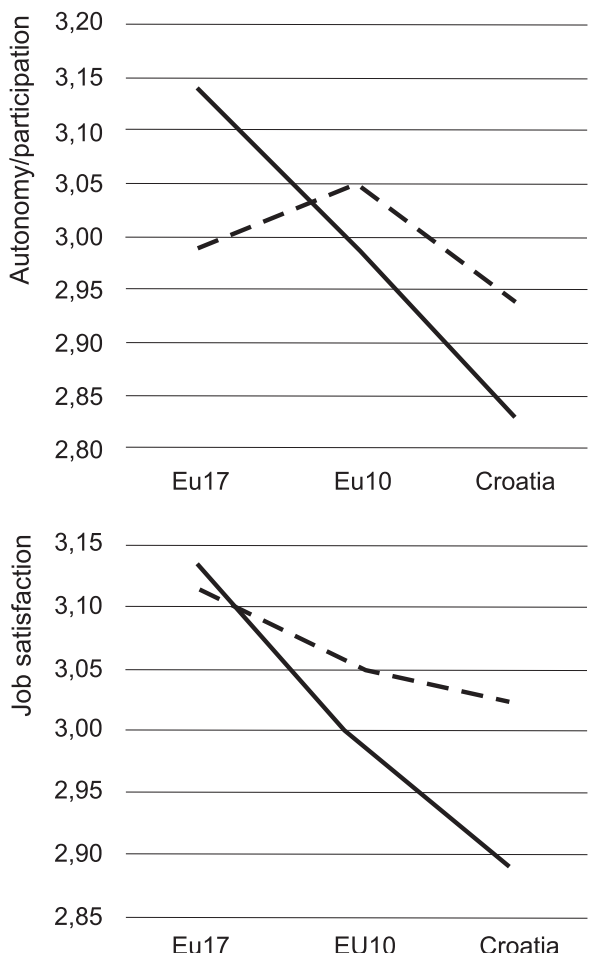
DRUŠ. ISTRAŽ. ZAGREB GOD. 28 (2019), BR. 1 STR. 69-87

GALIĆ, Z, PARMAČ KOVACIC, M. VEHOVEC, M.: QUALITY OF WORKING..
For the economic security component of QWL, the difference between older and younger workers is much larger in Croatia than in the EU17 countries. Even more interesting are the interactions between country and age for autonomy/participation in making decisions and job satisfaction. Whereas in EU17 countries older workers rate their autonomy/participation in work higher and are more satisfied with their jobs than younger workers, the situation in Croatia is reversed. In all cases, the trend among EU10 participants is similar to Croatia, but with less pronounced differences between younger and older workers.

\section{GENERAL DISCUSSION}

The main aim of our study was to contribute to the understanding of QWL and job satisfaction among older workers in Croatia. Having in mind current demographic trends, we believe that this is key for keeping them within the active workforce and away from voluntarily leaving the labor market before the full-retirement age. In our paper, we reported the results from the most recent pan-European study on the quality of working conditions where we compared QWL among older and younger workers both within Croatia and across the EU. Our study offers several contributions to the literature. First, research on QWL among Croatian workers is generally scarce, and studies that focus on older workers are nonexistent. Second, most of the studies exploring job attitudes and work motivation among older workers come from well-developed market economies such as the US or west European countries (Ng \& Feldman, 2010; 2012). Third, our study offers a cross-country comparison that is rare in the literature on the ageing workforce (Truxillo et al., 2015).

Our results showed that, across the EU, 50+ workers rated their economic security and social relations at work generally lower but job meaningfulness generally higher than younger workers. The findings related to QWL reflected in the general job satisfaction, which was generally lower among older participants. Croatian $50+$ participants had especially low ratings on the QWL dimensions of economic security and autonomy/participation in decision-making. They rated the two aspects of job quality lower than their peers from both groups of EU countries did.

Though not in the focus of our research, our study offered us a possibility to see what happened to the differences in QWL between Croatian and other EU workers reported by Šverko and Galić (2014). The main finding from that study was that EU workers coming from transitional countries (including Croatia) scored lower than did the workers from West 
DRUŠ. ISTRAŽ. ZAGREB GOD. 28 (2019), BR. 1, STR. 69-87

GALIĆ, Z., PARMAČ KOVACIĆ, M., VEHOVEC, M.: QUALITY OF WORKING..
European market economies on three out of four dimensions of the QWL: economic security, meaningfulness at work, and autonomy/participation in decision-making. At the same time, QWL ratings between Croatia and EU10 countries mostly did not differ. The data from the 6th EWCS confirmed the difference between Croatian and workers from well-developed EU economies. However, the 6th EWCS indicated that, regarding QWL, Croatia started to lag behind other transitional countries in economic security and autonomy/participation in decision-making. It is also interesting to note that favorable ratings of social relations at work, which were a comparative advantage of the Croatian workplace in Šverko and Galić's (2014) study, disappeared in the 6th EWCS dataset. We might speculate that prolonged recession took its toll and were reflected in the social relations at work.

Seen from the EU perspective, being an older worker in Croatia might be a double jeopardy when it comes to QWL. We believe that our findings, at least partially, explain why a large number of Croatian workers leave the labor market before full retirement age and why it is unreasonable to expect them to stay even longer at their workplace, as is it advised in recommendations that follow from the current demographic trends (e.g., the International Monetary Fund, 2017). They are not satisfied with their economic prospects at their jobs and they do not perceive that they are given enough opportunities to exercise their autonomy and participate in decisions important for their work.

The question in order is: what could be done to improve the situation among Croatian older workers? How could jobs be better fitted to the needs of older workers? It is difficult to expect that economic security indicators can easily be changed considering that this component of the QWL largely reflects the level of economic development in a country. For example, Šverko and Galić (2014) reported a large correlation between the EU-28 countries' score on this component and their GDP (Pearson $r=0.73$ ). While large rates of economic growth in Croatia could not be expected in the near future (European Commission, 2018), we believe that the changes that could enhance autonomy and participation in decision-making at the workplace are both desirable and realistic.

Though many interventions for effective age management are available (see Pološki Vokić \& Grgurić, 2011 for an overview), in this paper we focused on those that stem from job design literature. The job design literature offers at least two types of interventions as cost-effective and yet promising ways for the improvement of autonomy at work: encouragement of job crafting and training of managers to become more autonomy supportive. First, job crafting refers to the activities 
DRUŠ. ISTRAŽ. ZAGREB GOD. 28 (2019), BR. 1 STR. 69-87

GALIĆ $Z_{\text {. }}$ PARMAČ KOVACIĆ, $M$. VEHOVEC, M.: QUALITY OF WORKING. workers engage in to restructure cognitive or physical boundaries of their job tasks or to change their social relations at work (Wrzesniewski \& Dutton, 2001). For example, Dutton, Debebe, and Wrzesniewski (2001) reported results of a qualitative study that analyzed cleaners in one US hospital. The study showed that, regarding the way they think and feel about their jobs, cleaners could be divided into two groups. The first group consisted of cleaners that did only a necessary set of job tasks and engaged in a minimal number of social interactions at work. The cleaners from this group did not enjoy their duties, perceived that their job demands only a limited set of skills and did not show any inclinations towards changing their work tasks or social relations at work (i.e., job crafting). The other group of cleaners were "job crafters". They restructured their work obligations and social relations at work they carried out additional work tasks and initiated additional interactions with patients, visitors or other hospital's employees. The second group enjoyed their work, perceived that it demands a complex set of skills, and even facilitated job activities of other employees in their business unit. Thus, job crafting refers to "a creative and improvised process that captures how individuals locally adapt to their jobs in ways that create and sustain a viable definition of the work they do and who they are at work" (Wrzesniewski \& Dutton, 2001, p. 180). Earlier research (Tims \& Bakker, 2010) showed that through job crafting employees obtain control over their work and, therefore, satisfy their autonomy-related needs. In the case of our study, for example, older workers might be encouraged by the management to restructure their social relations at work and develop a mentoring relationship with younger colleagues of their choice. In addition to satisfaction of autonomy needs, this intervention would probably satisfy generativity needs (i.e., needs to leave something to the next generation) that become salient as people age (Kanfer \& Ackerman, 2004) but also help the transfer of knowledge in an organization.

Second, managers should be trained to be more autonomy supportive. According to the self-determination theory, currently one of the most influential work motivation theories (Kanfer, Frese, \& Johnson, 2017), there are several elements managers should be taught to create an autonomy-supportive work climate. First, they should learn to take the employees' perspective and see the workplace situation from "their shoes". Second, they should encourage employees to take more initiative, and, third, they need to learn how to give feedback that is informational and not controlling or demeaning for employees (Deci, Olafsen, \& Ryan, 2017). For example, Deci, Connell, and Ryan (1989) report the results of the evaluation of one such educational program in a Fortune 500 company. 
DRUŠ. ISTRAŽ. ZAGREB GOD. 28 (2019), BR. 1, STR. 69-87

GALIĆ, Z., PARMAČ

KOVACIC, M.,

VEHOVEC, M.:

QUALITY OF WORKING.
The intervention was conducted on a sample of 23 managers who were each in charge of 15 to 18 employees. The managers took part in a three-day offsite intervention where they were taught to take the employees' perspective, to encourage initiative among subordinates and to give informational feedback. After the education, the change agent observed how each of the managers implemented newly acquired knowledge with his/her subordinates, and gave them feedback afterwards. Evaluation of the intervention revealed the managers became more autonomy-supportive after the intervention and that this positive effect reflected on the employees who reported higher job satisfaction and greater trust in corporate management after the education.

Our study has several limitations three of which seem the most important. First, although the use of data from a pan-European study is beneficial in terms of sampling (i.e., size and representativeness of the sample), it leaves the researchers with measures they have not developed from the beginning and, thus, with potentially lower than expected psychometric characteristics. In our study, we used QWL scales with mediocre internal consistencies and a one-item measure of job satisfaction. While we were still able to observe significant and consistent effects even with these measures, future studies would profit from better indicators. Second, one could argue that, though significant, the observed effects are small in size $\left(\eta^{2}\right.$ for main effects ranged up to 0.005 and for interactions up to 0.002; Bachmann, Luccio, \& Salvadori, 2005), and might result from the circumstances that influenced the responses during data collection (e.g., economic conditions during 2015) and not real differences on the labor markets. Considering that we had available the dataset from the 5th EWCS that was used by Šverko and Galić (2014), we were able to test if the age differences and the age by gender interactions observed in our study already had existed in 2010. With the exception of the main effect of age in social relations, all other main effects and country by age interaction were also significant in the 5th EWCS. ${ }^{2}$ This points out that the observed differences are not the result of some temporary circumstances, but of a long-term unfavorable situation for older workers on the labor market. Finally, in our study we explored QWL in order to gain an understanding in the participation rates among older workers. However, it should be stressed that the rates are not a necessary outcome of voluntary decisions made by older workers, but might result from external factors, such as the consequences that the rapidly changing world of work has for the employability of older employees, or the fact that in the competition for a scarce number of job vacancies some employers might prefer younger to older workers. 


\section{CONCLUSION}

The need for older workers to stay employed longer is one of the most pressing consequences of the demographic trends in the EU. Though employers in Croatia generally seem to have favorable attitudes about older workers (Ograjenšek, Vehovec, Domadenik, \& Redek, 2008), our research shows that older workers in Croatia themselves perceive their QWL lower than younger Croatian workers and their EU peers. The differences are most pronounced in the case of perceived economic security and opportunity to exercise autonomy at work. We believe that this should be changed if we want to expect older workers to stay in employment until full retirement age and even work longer in the future.

\section{NOTES}

\section{APPENDIX}

1 We also explored the role of gender, level of education and employment sector as additional independent variables. Since the age trends remained the same, irrespective of these three variables, we present only age by country two-way ANOVAs.

2 Complete analysis of the 5th EWCS is available from the first author upon request.

Table A

Evidence for the construct validity of the Quality of working life (QWL) measure: Correlations of the QWL dimensions with general well-being

\begin{tabular}{lccc}
\cline { 2 - 4 } & \multicolumn{3}{c}{ Well-being } \\
\cline { 2 - 4 } & Total sample & Under 50 & $50+$ \\
\hline Economic security & $0.31^{* *}$ & $0.30^{* *}$ & $0.31^{* *}$ \\
Social relations & $0.32^{* *}$ & $0.33^{* *}$ & $0.31^{* *}$ \\
Meaningfulness of work & $0.33^{* *}$ & $0.34^{* *}$ & $0.31^{* *}$ \\
Autonomy and participation & $0.22^{* *}$ & $0.20^{* *}$ & $0.27^{* *}$
\end{tabular}

Note: Well-being was assessed with five items that asked how the participant generally felt over the two weeks preceding the survey (e.g. "I have felt cheerful and in good spirits."; response scale: 1 = at no time, 6 = all the time, Cronbach's alpha for the scale was 0.88 ); ${ }^{* *} p<0.01$.

\section{REFERENCES}

Alderfer, C. P. (1972). Existence, relatedness, and growth: Human needs in organizational settings. New York: Free Press.

Attewell, P., \& Rule, J. (1984). Computing and organizations: What we know and what we don't know. Communications of the ACM, 27(12), 1184-1192. https://doi.org/10.1145/2135.2136 
DRUŠ. ISTRAŽ. ZAGREB GOD. 28 (2019), BR. 1, STR. 69-87

GALIĆ $Z_{\text {., PARMAČ }}$ KOVACIC, M., VEHOVEC, M.: QUALITY OF WORKING..
Baloković, S. (2010). Prijevremeno umirovljenje u Republici Hrvatskoj [Early retirement in the Republic of Croatia]. Revija za socijalnu politiku, 18(1), 61-76. https://doi.org/10.3935/rsp.v18i1.976

Davis, L. E. (1983). Design of new organizations. In H. Kolodny, \& H. Van Beinum (Eds.), The quality of working life and the 1980s (pp. 65-86). New York: Praeger.

Deci, E. L., \& Ryan, R. M. (1985). Intrinsic motivation and self-determination in human behavior. New York: Plenum. https://doi.org/10.1007/ 978-1-4899-2271-7

Deci, E. L., \& Ryan, R. M. (2000). The "what" and "why" of goal pursuits: Human needs and the self-determination of behavior. Psychological Inquiry, 11(4), 227-268. https://doi.org/10.1207/S15327965PLI11 04_01

Deci, E. L., Connell, J. P., \& Ryan, R. M. (1989). Self-determination in a work organization. Journal of Applied Psychology, 74(4), 580-590. https://doi.org/10.1037/0021-9010.74.4.580

Deci, E. L., Olafsen, A. H., \& Ryan, R. M. (2017). Self-determination theory in work organizations: The state of a science. Annual Review of Organizational Psychology and Organizational Behavior, 4, 19-43. https://doi.org/10.1146/annurev-orgpsych-032516-113108

Dutton, J. E., Debebe, G., \& Wrzesniewski, A. (2001). A social valuing perspective on relationship sense making. Working paper. Ann Arbor: University of Michigan.

Efraty, D., \& Sirgy, M. J. (1990). The effects of quality of working life (QWL) on employee behavioral responses. Social Indicators Research, 22(1), 31-47. https://doi.org/10.1007/BF00286389

Eurofound (2012). Fifth European Working Conditions Survey. Luxembourg: Publications Office of the European Union.

Eurofound (2017). Sixth European Working Conditions Survey - Overview report (2017 update). Luxembourg: Publications Office of the European Union.

European Commission (2016). Facts and figures: Healthy workplaces campaign for all ages 2016-17. Available at http://europa.eu/rapid/pressrelease_MEMO-16-1421_en.htm

European Commission (2018). The 2018 ageing report: Economic and budgetary projections for the EU member states (2016-2070). Available at https://ec.europa.eu/info/publications/economy-finance/2018-ageing-report-economic-and-budgetary-projections-eu-member-states2016-2070_en

Eurostat (2015a). Fertility statistics. Available at http://ec.europa.eu/ eurostat/statistics-explained/index.php/Fertility_statistics

Eurostat (2015b). Mortality and life expectancy statistics. Available at http://ec.europa.eu/eurostat/statistics-explained/index.php/Mortality_ and_life_expectancy_statistics

Galić, Z., \& Plećaš, M. (2012). Quality of working life during the recession: The case of Croatia. Croatian Economic Survey, 14, 5-41.

Hackman, J. R., \& Oldham, G. R. (1976). Motivation through the design of work: Test of a theory. Organizational Behavior and Human Performance, 16(2), 250-279. https://doi.org/10.1016/0030-5073(76)90016-7 
DRUŠ. ISTRAŽ. ZAGREB GOD. 28 (2019), BR. 1 STR. $69-87$

GALIĆ, Z, PARMAČ KOVACIĆ, M. VEHOVEC, M.: QUALITY OF WORKING..
Havlovic, S. J. (1991). Quality of work life and human resource outcomes. Industrial Relations: A Journal of Economy and Society, 30(3), 469-479. https://doi.org/10.1111/j.1468-232X.1991.tb00799.x

Hoff, A. (Ed.) (2011). Population ageing in Central and Eastern Europe: Societal and policy implications. Surrey, England: Ashgate Publishing Limited.

Huang, T. C., Lawler, J., \& Lei, C. Y. (2007). The effects of quality of work life on commitment and turnover intention. Social Behavior and Personality: An International Journal, 35(6), 735-750. https://doi.org/10. 2224/sbp.2007.35.6.735

International Monetary Fund (2017). Republic of Croatia: Staff concluding statement of the 2017 Article IV Mission. Available at https://www. imf.org/en/News/Articles/2017/10/26/mcs102717-republic-of-croatiastaff-concluding-statement-of-the-2017-article-iv-mission

Judge, T. A., \& Klinger, R. (2007). Job satisfaction: Subjective well-being at work. In M. Eid, \& R. Larsen (Eds.), The science of subjective well-being (pp. 393-413). New York: Guilford Publications.

Kanfer, R., \& Ackerman, P. L. (2004). Aging, adult development, and work motivation. Academy of Management Review, 29(3), 440-458. http://dx. doi.org/10.2307/20159053

Kanfer, R., Frese, M., \& Johnson, R. E. (2017). Motivation related to work: A century of progress. Journal of Applied Psychology, 102(3), 338-355. https://doi.org/10.1037/apl0000133

Koonmee, K., Singhapakdi, A., Virakul, B., \& Lee, D. J. (2010). Ethics institutionalization, quality of work life, and employee job-related outcomes: A survey of human resource managers in Thailand. Journal of Business Research, 63(1), 20-26. https://doi.org/10.1016/j.jbusres.2009. 01.006

Korunka, C., Hoonakker, P., \& Carayon, P. (2008). Quality of working life and turnover intention in information technology work. Human Factors and Ergonomics in Manufacturing $\mathcal{E}$ Service Industries, 18(4), 409-423. https://doi.org/10.1002/hfm.20099

Kraut, R., Dumais, S., \& Koch, S. (1989). Computerization, productivity, and quality of work life. Communications of the ACM, 32(2), 220-238. https://doi.org/10.1145/63342.63347

Lee, D. J., Singhapakdi, A., \& Sirgy, M. J. (2007). Further validation of a need-based quality-of-work-life (QWL) measure: Evidence from marketing practitioners. Applied Research in Quality of Life, 2, 273-287. https://doi.org/10.1007/s11482-008-9042-x

Louis, K. S. (1998). Effects of teacher quality of work life in secondary schools on commitment and sense of efficacy. School Effectiveness and School Improvement, 9(1), 1-27. https://doi.org/10.1080/0924345980090101

Maslow, A. H. (1954). Motivation and personality. New York: Hape.

McClelland, D. C. (1985). Human motivation. NY: Cambridge University Press.

Naylor, J. C., Pritchard, R. D., \& Ilgen, D. R. (1980). A theory of behavior in organizations. Academic Press.

Ng, T. W., \& Feldman, D. C. (2010). The relationships of age with job attitudes: A meta-analysis. Personnel Psychology, 63(3), 677-718. https://doi. org/10.1111/j.1744-6570.2010.01184.x 
DRUŠ. ISTRAŽ. ZAGREB GOD. 28 (2019), BR. 1, STR. 69-87

GALIĆ, Z, PARMAČ KOVACIC, M., VEHOVEC, M.: QUALITY OF WORKING..
Ng, T. W., \& Feldman, D. C. (2012). Evaluating six common stereotypes about older workers with meta-analytical data. Personnel Psychology, 65(4), 821-858. https://doi.org/10.1111/peps.12003

Ograjenšek, I., Vehovec, M., Domadenik, P., \& Redek, T. (2008). Employer attitudes towards older workers: A comparative study of Croatia and Slovenia. In M. Vehovec (Ed.), New perspectives on longer working life in Croatia and Slovenia (pp. 119-140). Zagreb: The Institute of Economics and Friedrich Ebert Stiftung.

Pološki Vokić, N., \& Grgurić, L. (2011). Upravljanje zaposlenicima starije životne dobi - model djelotvornog upravljanja u hrvatskim organizacijama [Age management - the development of an effective model for Croatian organizations]. Revija za socijalnu politiku, 18(2), 149-174. https://doi.org/10.3935/rsp.v18i2.1006

Raynor, J. O. (1982). A theory of personality functioning and change. In J. O. Raynor, \& E. E. Entin (Eds.), Motivation, career striving, and aging (pp. 249-302). Washington, D.C.: Hemisphere Publishing Corp. Šverko, B., \& Galić, Z. (2009). Kvaliteta radnog života u Hrvatskoj: subjektivne procjene tijekom posljednjih 15 godina [Quality of working life in Croatia: Subjective ratings during the last 15 years]. In V. Franičević, \& V. Puljiz (Eds.), Rad u Hrvatskoj: pred izazovima budućnosti [Work in Croatia: In front of the challenges of the future], (pp. 197-223). Zagreb: Centar za demokraciju i pravo Miko Tripalo and Pravni fakultet Sveučilišta u Zagrebu.

Šverko, B., \& Galić, Z. (2014). The perceived quality of working life in Croatia and the European Union. Društvena istraživanja, 23(4), 557-575. https://doi.org/10.5559/di.23.4.01

Tims, M., \& Bakker, A. B. (2010). Job crafting: Towards a new model of individual job redesign. SA Journal of Industrial Psychology, 36(2), 1-9. https://doi.org/10.4102/sajip.v36i2.841

Truxillo, D. M., Cadiz, D. M., \& Hammer, L. B. (2015). Supporting the aging workforce: A review and recommendations for workplace intervention research. Annual Review of Organizational Psychology and Organizational Behavior, 2, 351-381. https://doi.org/10.1146/annurev-orgpsych-032414-111435

Vehovec, M. (Ed.) (2008). New perspectives on longer working life in Croatia and Slovenia. Available at http://www.eizg.hr/en-US/New-Perspectives-on-a-Longer-Working-Life-in-Croatia-and-Slovenia-360.aspx

Wrzesniewski, A., \& Dutton, J. E. (2001). Crafting a job: Revisioning employees as active crafters of their work. Academy of Management Review, 26(2), 179-201. http://dx.doi.org/10.2307/259118

Župarić-Iljić, D. (2016). Globalni izazovi i "ljudi u pokretu": multiplikacija i diverzifikacija uzročnika nedobrovoljnih migracija u suvremenom svijetu [Global challenges and "people on the move": Multiplication and diversification of involuntary migration causes in the modern world]. In Dani kriznog upravljanja (Crisis Management Days) - Zbornik radova (Book of Papers) (pp. 667-673). Velika Gorica: Veleučilište Velika Gorica. 
DRUŠ. ISTRAŽ. ZAGREB GOD. 28 (2019), BR. 1 STR. $69-87$

GALIĆ, Z, PARMAČ

KOVACIC, M.,

VEHOVEC, M.:

QUALITY OF WORKING.
Kvaliteta radnoga života zaposlenika stariiih od 50 godina u EU-u: dvostruki izazov za starije hrvatske radnike

Zvonimir GALIĆ, Maja PARMAČ KOVAČIĆ

Filozofski fakultet, Zagreb

Maja VEHOVEC

Ekonomski institut, Zagreb

Jedan od trenutačno važnijih problema Europske unije jest utjecaj starenja stanovništva na gospodarstvo, posebno mirovinske i zdravstvene sustave. U Hrvatskoi je taj problem još izraženiiji jer dobar dio radne snage napušta tržište rada prije zakonske dobi umirovljenja. Jedan od mogućih razloga za prijevremeno umirovljenje mogla bi biti kvaliteta radnoga života starijih zaposlenika. Cili je našeg rada bio istražiti kvalitetu radnoga života starijih zaposlenika u Hrvatskoj. Upotrebom podataka prikuplienih u okviru Šeste europske ankete o radnim uvjetima, koja je provedena 2015. na više od 30000 sudionika, usporedili smo kvalitetu radnoga života hrvatskih radnika stariiih od 50 godina s mlađim radnicima i njihovim vršnjacima iz razvijenih tržišnih ekonomija Zapadne Europe (EU17) i tranzicijskih zemalja Srednje i Istočne Europe (EU10). Nalazi istraživanja pokazali su da stariji radnici u Hrvatskoj smatraju kvalitetu svojega radnog života nižom od mlađih hrvatskih radnika i njihovih vršnjaka iz drugih EU zemalja (posebice ekonomsku sigurnost i autonomiju u poslu). Vjerujemo da su ti nalazi, barem djelomično, razlog prijevremenog umirovljenja starijih radnika.

Ključne riječi: stariii radnici, kvaliteta radnoga života, kvaliteta posla, zadovoljstvo poslom, Hrvatska, Europska unija

\section{(c) (i) (8)}

Međunarodna licenca / International License:

Imenovanje-Nekomercijalno/ Attribution-NonCommercial 